\title{
Menumbuhkan Nilai Kewirausahaan Dan Daya Saing Pelaku Usaha Mikro Kecil Di Desa Pengulu, Kecamatan Sidayu, Kabupaten Gresik
}

\author{
Sutama Wisnu Dyatmika ${ }^{1}$, Tony Susilo Wibowo ${ }^{2}$, Subakir $^{3}$, Untung Lasiyono ${ }^{4}$ \\ 12 Program Studi Manajemen, Fakultas Ekonomi, Universitas PGRI Adi Buana Surabaya \\ ${ }^{34}$ Program Studi Akuntansi, Fakultas Ekonomi, Universitas PGRI Adi Buana Surabaya \\ E-mail : sutama@unipasby.ac.id
}

\begin{abstract}
ABSTRAK
Kewirausahaan dapat menyerap banyak tenaga kerja sehingga mampu menurunkan angka kemiskinan dan pengangguran. Saat ini semua negara terus memperhatikan perkembangan dunia wirausaha mulai dari sektor agraris hingga sektor financial technology. Semua berupaya agar segala sektor yang ada dapat saling berkaitan dan membentuk sebuah pola ekosistem kuat guna menopang perekonomian negara. Demikian halnya yang terjadi di Desa Pengulu Kabupaten Gresik, di desa ini usia produktif lebih memilih untuk bekerja di kota besar terdekatnya yaitu Surabaya. Maka yang terjadi adalah tidak ada penggerak kewirausahaan yang potensial di desa ini. Padahal desa memiliki potensi olahan ikan yang sangat baik mengingat lokasi desa ini relatif dekat dengan pesisir. Untuk itu dilakukanlah program pengabdian masyarakat di Desa Pengulu, Sidayu, Gresik. Program ini dilakukan dengan rangkaian proses: Penyampaian Materi Mindset Kewirausahaan, Pemberian Contoh Sederhana, Nyata, dan Bisa Diduplikasi, dan Konsultasi Teknis dan Optimalisasi Aktivitas. Setelah dilakukan kegiatan ini, masyarakat menjadi sadar dan mnegrti pentingnya kewirausahaan. Bagi masyarakat yang telah melakukan aktivitas kewirausahaan ditemukan beberapa kendala yang akan dicari solusinya agar kedepannya mendapatkan hasil yang lebih baik.
\end{abstract}

Kata kunci : kewirausahaan, masyarakat, potensi desa

\begin{abstract}
Entrepreneurship can absorb a lot of workers so as to reduce poverty and unemployment. Currently all countries continue to pay attention to the development of the entrepreneurial world ranging from the agricultural sector to the financial technology sector. All strive so that all existing sectors can be interconnected and form a strong ecosystem pattern to sustain the country's economy. Likewise, what happened in Pengulu Village, Gresik Regency, in this village the productive age prefers to work in the nearest big city, Surabaya. So what happens is there are no potential entrepreneurial drivers in this village. Even though the village has a very good potential of processed fish considering the location of this village is relatively close to the coast. For this reason, a community service program was conducted in Pengulu Village, Sidayu, Gresik. The program is carried out with a series of processes: Submission of Entrepreneurial Mindset Materials, Providing Simple, Real, and Replicable Examples, and Technical Consultation and Activity Optimization. After this activity was carried out, the community became aware and understood the importance of entrepreneurship. For people who have carried out entrepreneurial activities, several obstacles will be found that will be sought a solution so that in the future get better results.
\end{abstract}

Keywords : entrepreneurship, community, village potential 


\section{PENDAHULUAN}

Salah satu indikator negara maju dapat dilihat dari rasio jumlah wirasuaha yang ada di negara tersebut. Semakin tinggi tingkat rasionya maka dapat dipastikan negara tersebut akan semakin baik dari segala sisi khususnya dari sisi ekonomi. Setiap negara berlomba-lomba untuk memperbesar jumlah wirausaha. Hal ini menjadi sangat relevan berkaitan dengan pasar bebas dan kian melesatnya perkembangan teknologi. Pemerintah dalam suatu negara akan mengalami keterbatasan apabila tidak diiringi dengan berkembangnya sektor kewirausahaan. Kewirausahaan dapat menyerap banyak tenaga kerja sehingga mampu menurunkan angka kemiskinan dan pengangguran. Saat ini semua negara terus memperhatikan perkembangan dunia wirausaha mulai dari sektor agraris hingga sektor financial technology. Semua berupaya agar segala sektor yang ada dapat saling berkaitan dan membentuk sebuah pola ekosistem kuat guna menopang perekonomian negara.

Demikain halnya yang terjadi di Indonesia, pemerintah terus memberikan stimulus pengetahuan dan dukungan dana bagi pelaku kewirausahaan. Pemerintah menyadari bahwa bangsa ini memiliki potensi yang masih sangat bisa dioptimalkan. Potensi bukanlah sekedar angan-angan karena apabila dilihat dari rasio kewirausahaan di Indonesia jumlahnya selalu meningkat. Menurut data Kementrian Koperasi dan UKM pada tahun 2014 (https://www.antaranews.com/berita/761556/rasio-kewirausahaanindonesia-naik-dalam-empat-tahun-terakhir) rasio kewirausahaan masih 1,4\% dan pada tahun 2016 naik menjadi 3,1\% sehingga diharapkan pada akhir 2019 rasio ini dapat naik minimal berada pada rasio 5\%. Dengan naiknya rasio ini Indonesia terus berusaha agar dapat melebihi negara-negara yang ada disekitarnya yaitu Singapura sebesar 7\% dan malaysia sebesar 5\% (Helisia, 2019). Banyak sekali dukungan Pemerintah kaitannya dengan hal ini misalnya saja dengan dibentuknya GKN (Gerakan Kewirausahaan Nasional) dan GMP (Gerakan Mahasiswa Pengusaha). Kedua gerakan ini tentunya akan meningkatkan rasio kewirausahaan di Indonesia. Dari sisi perpajakan pun Pemerintah memberikan kelonggaran nilai pajak yang sangat kecil yaitu sebesar 5\% dari omset dengan tata cara pelaporan pajak yang sangat sederhana. Masih banyak lagi hal yang dilakukan oleh pemerintah melalui lintas kementrian yang ada. Pentingnya wirausaha di dalam masyarakat tersebut tidak sekedar menjadi 'alat' untuk melakukan perbaikan dan perubahan di dalam kualitas hidup diri dan masyarakat, tetapi juga wirausaha juga dibuktikan dapat berperan signifikan di dalam mewujudkan kualitas diri masyarakat dan bangsa (Frinces, 2010). Semua aktivitas tadi ditujukan untuk menstimulus agar masyarakat lebih tertarik melakukan aktivitas kewirausahaan guna turut serat menggerakan roda perekonomian bangsa. Minimnya jumlah wirausaha merupakan permasalahan bersama bangsa Indonesia. Pihak-pihak yang bertanggung jawab bukan hanya pemerintah, namun seluruh warga negara Indonesia. Hal inilah yang menyebabkan perlunya para wirausaha muda di Indonesia (Wahyu, Dwi. 2016). Munculah pertanyaan, bagaimana cara untuk menciptakan wirausaha-wirausaha baru sementara di lingkungan pendidikan pun tidak memberikan penekanan terhadap hal ini. 
Dari yang disampaiakn sebelumnya memberikan pengertian bahwa sekolah hanyalah sebuah batu loncatan untuk menciptakan pekerjaan sesuai dengan bidang keahlian yang diikutinya dan bukan mengharapkan mendapatkan pekerjaan dengan mencari pekerjaan di sekeliling kota.(Anggraini, 2015). Segala akses tentang dukungan kewirausahaan bagi masyarakat yang tinggal di perkotaan mungkin bukanlah kendala yang berarti karena segala informasi dapat diperoleh dengan cara yang mudah, sementara bagi masyarakat yang tinggal di pedesaan rasanya lebih sulit untuk mendapatkan akses informasi seperti itu. Demikian halnya yang terjadi di Desa Pengulu Kabupaten Gresik, di desa ini usia produktif lebih memilih untuk bekerja di kota besar terdekatnya yaitu Surabaya. Maka yang terjadi adalah tidak ada penggerak kewirausahaan yang potensial di desa ini. Padahal desa memiliki potensi olahan ikan yang sangat baik mengingat lokasi desa ini relatif dekat dengan pesisir. Dari sinilah tim pengabdian masyarakat tertarik untuk memberikan penguatan nilai-nilai kewirausahaan sekaligus memperkuat daya saing atas aktivitas yang telah dilakukan oleh UKM yang ada. Untuk melakukan kegiatan ini tentunya memiliki tantangan tersendiri karena mayoritas pelaku usahan adalah masyarakat yang usianya sudah lebih dari usia produktif (berkisar antara 40-50tahun). Edukasi semacam ini harus terus dilakukan agar ketika sudah menunjukan hasil yang dapat menunjang kesejahteraan keluarga dari sisi ekonomi maka dapat dipastikan banyak generasi muda yang tertarik untuk kembali ke desa dan menajukan negara melalui roda kewirausahaan yang dilakukan dari desa.

\section{METODE PELAKSANAAN}

Pelaksanaan pengabdian ini dilakukan dengan teknik pemberian materi kepada masyarakat agar para pelaku UKM di Desa Pengulu benar-benar mengerti dan paham atas aktivitas kewirausahaan yang telah dilakukan saat ini. Materi ini diberikan dengan cara yang sangat dasar sehingga masyarakat dapat mengetahui bagaimana carannya mengembangkan usaha yang telah dilakukan dan membuat faktor kali dalam bisnis yang ada. Teknik semacam ini tidak akan berhasil apabila tidak ada contoh yang kongkrit atas keberhasilan metode yang ada sehingga pada materi ini disisipi pula beberapa contoh kongkrit para pelaku UKM yang telah berhasil dan sama-sama dimulai dari desa. Kemudian setelah selesai dengan pemberian materi dilanjutkan dengan tes kecil dengan beberapa pertanyaan yang mengindikasikan bahwa masyarakat sudah paham dan benarbenar mengerti apa yang disampaikan sebelumnya. Setelah memastikan masyarakat paham maka proses pengabdian ini dilanjutkan dengan sesi konsultasi teknis bagi masyarakat yang telah memiliki produk. Konsultasi ini meliputi perbaikan produk serta cara menjual non-konvensional sehingga dapat menambah chanel penjualan dan pada akhirnya dapat menambah omset UKM tersebut.

Materi dan sesi konsultasi teknis yang disampaikan kepada masyarakat secara garis besar dapat dibagi menjadi beberapa tahap sebagai berikut:

(1) Penyampaian Materi Mindset Kewirausahaan

Tahapan pertama ini merupakan tahapan yang sangat penting karena dapat dipastikan apabila pada tahap ini gagal atau tidak tersampaikan dengan baik maka tahap berikutnya 
juga tidak akan berjalan dengan maksimal. Pada tahap ini masyarakat benar-benar diberikan pemahaman dasar mengenai kewirausahaan dan kenapa kewirausahaan ini harus terus diperkuat dan volumenya diperbesar. Pada tahap ini pula diberikan perbandingan antara berwirausaha dengan non-wirausaha sehingga masyarakat menjadikan aktivitas kewirausahaan ini sebagai langkah utama tidak hanya sebatas karena kondisi yang tidak memungkinkan untuk melakukan hal lain.

(2) Pemberian Contoh Sederhana, Nyata, dan Bisa Diduplikasi

Contoh menjadi hal yang penting karena pada umumnya masyarakat tidak terlalu antusias untuk melakukan sesuatu hal apabila tidak ada contoh yang dapat mereka ketahui secara pasti. Pada tahap ini langsung diberikan contoh nyata bagaimana proses kewirausahaan dilakukan sekaligus hasil yang diperoleh ketika aktivitas usaha yang dilakukan dijalani dengan penuh keseriusan. Komoditas yang dijadikan contoh pada tahap ini pun menggunakan contoh yang usahanya tidak berlebihan misalnya usaha makana ringan kerupuk. Usaha ini nampak sederhana namun apabila dikelola dengan profesional maka hasinya juga tidak bisa dianggap sebelah mata.

(3) Konsultasi Teknis dan Optimalisasi Aktivitas

Pada tahap ini tidak semua masyarakat terlibat namun hanya masyarakat yang telah memiliki atau menjalankan usaha saja. Tentunya pada tahap ini jumlah masyarakat yang terlibat tidak sebanyak tahap sebelumnya. Masyarakat yang memiliki usaha akan dikategorikan berdasarkan jenis usahanya untuk mempermudah sesi konsultasi teknis sekaligus antar usaha dapat melakukan sharing guna mencari solusi atas kendala-kendala yang selama ini dihadapai.

Apabila ketiga tahapan ini dilaksanakan dengan maksimal maka luaran akhir dari pengabdian ini diharapkan terlihat pada peningkatan omset UKM. Peningkatan omset akan membuat usaha semakin berkembang dan menjadi stimulus bagi masyarakat lain yang belum melakukan aktivtas wirausaha.

Tabel 1. Tahap Pelaksanaan dan Target Luarannya

\begin{tabular}{|c|c|c|}
\hline Tahap & Proses & Target Luaran \\
\hline 1 & $\begin{array}{l}\text { Penyampaian Materi } \\
\text { Mindset } \\
\text { Kewirausahaan }\end{array}$ & $\begin{array}{lrr}\text { Masyarakat } & \text { memahami } & \text { secara } \\
\text { mendasar mengapa } & \text { perlu } \\
\text { melakukan } & & \text { proses } \\
\text { kewirausahaan. } & \end{array}$ \\
\hline 2 & $\begin{array}{l}\text { Pemberian Contoh } \\
\text { Sederhana, Nyata, dan } \\
\text { Bisa Diduplikasi }\end{array}$ & $\begin{array}{l}\text { Masyarakat mulai menyadari } \\
\text { bahwa yang disampaikan pada } \\
\text { tahap } 1 \text { adalah sesuatu yang } \\
\text { dapat diraih karena banyak } \\
\text { contoh nyata. }\end{array}$ \\
\hline 3 & $\begin{array}{l}\text { Konsultasi Teknis dan } \\
\text { Optimalisasi Aktivitas }\end{array}$ & $\begin{array}{l}\text { Masyarakat mendapatkan solusi } \\
\text { atas kendala yang dialami } \\
\text { sekaligus membuka peluang } \\
\text { untuk meningkatkan omset } \\
\text { penjualan. }\end{array}$ \\
\hline
\end{tabular}




\section{HASIL DAN PEMBAHASAN}

Setelah dilakukan ketiga proses pengabdian ini maka ada beberapa hal yang dapat diperoleh oleh masyarakat disetiap tahapannya. Pada tahap pertama mungkin masyarakat banyak yang belum mengerti tentang nilai-nilai kewirausahaan sekaligus mindset yang mendasari mengapa mereka harus melalukan aktivitas ini. Bahkan ketika disampaikan bahwa dengan berwirausaha masyarakat dapat menjadi bagian dari pejuang ekonomi yang akan membawa bangsa ini menjadi negara maju. Hal ini tentu saja membutuhkan jumlah wirausaha setidaknya $14 \%$ dari total rasio penduduk Indonesia. Kemudian ketika disampaikan satu persatu nilai dari kewirausahaan masyarakat mulai terbuka bahwa manfaat dari berwirausaha sangat banyak sekali diantarannya menjadikan dan menambah rasa percaya diri. Setiap wirausaha pasti memiliki rasa percaya diri yang besar karena dalam mengelola usaha diperlukan banyak han yang bersumber dari keyakinan diri sendiri. Kemudian pola komunikasi dengan orang lain akan terbangun lebih baik karena tidak mungkin seorang wirausaha tidak berhubungan dengan orang lain, setidaknya mereka harus berhubungan dengan suplier dan customer. Tanpa disadari kemampuan menjalin hubungan baik dengan orang lain akan semakin kuat dan salah satu kunci sukses berwirausaha adalah adanya relasi yang baik dan kuat dengan semua pemangku kepentingan yang terlibat di dalamnya.

Kemudian nilai berikutnya adalah pengetahuan dan pengalaman, banyak masyarakat yang tidak mengerti bahwa pengetahuan dan pengalaman sebenarnya adalah aset tidak terlihat yang nilainya sangat tinggi. Dengan kata lain apabila tingkat pengetahuan dan pengalamannya sudah baik maka akan meminimalisir resiko yang mungkin saja datang secara tiba-tiba. Nilai yang tidak disadari kembali oleh masyarakat adalah adanya sikap inovatif. Sikap inilah yang diperlukan ketika mengalami beberapa kondisi tidak normal dalam bisnis akibat faktor-faktor eksternal. Katakanlah tiba-tiba negara mengalami krisis ekonomi maka hal apa yang akan dilakukan terhadap bisnis, tentunya ini tidak akan lepas dari sikap inovatif. Hal ini tidak dapat muncul begitu saja, semuanya akan semakin baik seiring dengan berjalannya waktu.

Pada tahap pemberian contoh masyarakat sempat haran karena contoh yang diberikan sebenarnya adalah contoh-contoh sederhana yang sangat dekat dengan kehidupan masyarakat sehari-hari. Salah satunya diberikan contoh bagaimana seorang penjual krupuk yang harga satu kerupuknya sebenarnya tidak mahal namun saat ini penjual kerupuk tadi dapat memiliki beberapa property bahkan mobil mewah. Disini diputarkan video juga sehingga masyarakat lebih sadar dan paham bahwa dalam menjalankan aktivitas kewirausahaan tidaklah diperlukan sesuatu hal yang rumit. Lakukan saja hal-hal sederhana yang bisa dilakukan secara konsisten dan pastikan bahwa setiap proses yang dilakui harus selalu bertumbuh karena pada umumnya masyarakat memiliki mental block yang membuat para pelau usaha sulit untuk berkembang. Tahap yang terakhir dilakukas sesi konsultasi dimana mayoritas masyarakat melakukan aktivitas pada jenis usaha makanan ringan yang terbuat dari olehan ikan. Rasa dari makanan ini sudah cukup baik namun proses pemasaran yang dilakukan terkendala pada daya tahan makanan yang tidak lama. Kedepannya akan dilakukan riset bersama untuk membuat daya tahan makanan ini 
bertahan semakin lama dengan mengacu pada salah satu oleh-oleh dari Kota Jogja yaitu gudeg yang sudah berinovasi menjadi gudeg kaleng dan dapat dinikmati dengan jangka waktu yang lebih lama sekaligus memiliki kepraktisan dari sisi pengiriman.

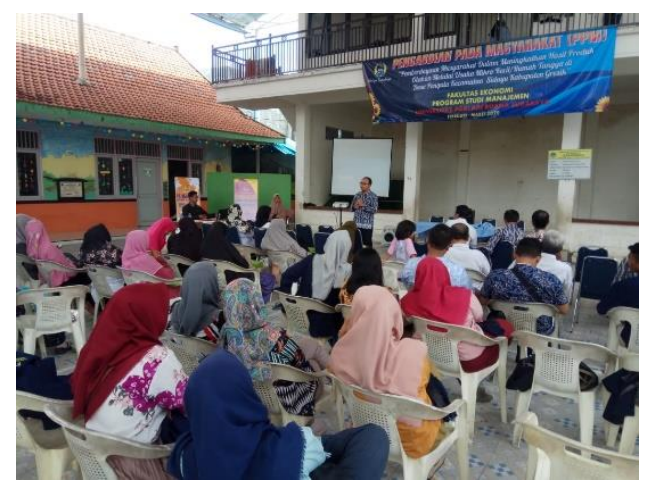

Gambar 1. Proses Pemberian Materi Kepada Masyarakat

\section{DAMPAK DAN MANFAAT KEGIATAN}

Setelah dilakukan pengabdian ini masyarakat Desa Pengulu mendapatkan pengertian baru yang sangat mendasar tentang nilai kewirausahaan. Masyarakat menjadi paham sebenarnya hal apa yang membuat seorang wirausaha menjadi sangat penting dari berbagai sisi. Sebagian besar masyarakat yang mengikuti setiap tahap pada proses pengabdian masyarakat ini banyak mendapatkan insight baru dan akan segera menerapkan ilmu yang diperoleh. Penerapannya pun akan dilakukan dengan sederhana, konsisten, dan pantang menyerah. Mereka telah mengetahui bahwa dunia usaha tentunya tidak akan berjalan dengan lancar dan justru dengan adanya problem akan menjadikan usaha yang dilakukan semakin kuat dan mampu berkembang.

Bagi masyarakat yang telah melakukan proses wirausaha khususnya dalam bidang makanan ringan olahan hasil laut mendapatkan tantangan baru atas masalah utama yang saat ini sedang dihadapi yaitu bagaimana caranya agar makanan yang diproduksi dapat bertahan dengan lama. Ketika daya tahannya lebih panjang maka akan disiapkan pula chanel-chanel penjualan baru yang akan membuat omset naik sekaligus hal yang tidak kalah penting adalah keterlibatan banyak masyarakat yang akan bersama-sama mendongkrak roda perekonomian dari desa.

\section{SIMPULAN}

Masyarakat yang hadir dalam rangkaian pengabdian ini tentunya benar-benar mengerti mengapa nilai kewirausahaan menjadi sangat bernilai karena apabila ini berjalan dengan lancar maka yang akan merasakan manfaatnya tidak hanya satu dua orang saja namun bisa jauh lebih banyak dari itu. Tujuan dari dilakukannya pengabdian di Desa Pengulu pun sudah tercapai dimana masyarakat menjadi paham dan sadar sekaligus mendapatkan titik baru tentang hal apa yang harus dilakukan setelah ini. Bagi masyarakat yang telah memiliki usaha pun merasa terbantu karena dengan adanya pengabdian ini mereka menjadi mampu memetakan kondisi bisnisnya saat ini termasuk kendala utama yang sedang dihadapi yaitu masalah daya tahap produk sehingga proses pemasaran yang 
dapat dilakukan pun menjadi sangat terbatas. Kedepannya akan dilakukan riset bersama secara teknis untuk menyelesaikan kendala tersebut sekaligus mempersiapkan chanelchanel pemasaran baru yang selama ini belum digunakan oleh masyarkat.

\section{UCAPAN TERIMA KASIH}

Terimakasih kami sampaikan kepada semua pihak yang telah berperan dalam mensukseskan rangkaian tahapan dalam pengabdian masyarakat ini diantarannya yang paling utama dalah masyarakat Desa Pengulu, Kecamatan Sidayu, Kabupaten Gresik atas semangatnya untuk tetap berperan dalam menggerakkan roda perekonomian dari desa. Terimakasih pula kami haturkan kepada LPPM Universitas PGRI Adi Buana Surabya beserta dengan segala komponen di Universitas. Kepada pihak Pemerintah Desa Sidayu diucapkan terimakasih atas koordinasi dan kerjasama yang baik sehingga proses ini dapat berjalan dengan lancar dan masyarakat mendapatkan manfaat yang sebesar-besarnya.

\section{DAFTAR PUSTAKA}

Anggraini, Bety dan Harnanik. (2015). Pengaruh Pengetahuan Kewirausahaan dan Lingkungan Keluarga Terhadap Minat Berwirausaha Siswa Kelas XI SMK Islam Nusantara Comal Kabupaten Pemalang. Jurnal Pendidikan Ekonomi Dinamika Pendidikan Vol. X No. 1, 42-52.

Frinces, Z. Heflin. (2010). Pentingnya Profesi Wirausaha Di Indonesia. Jurnal Ekonomi \& Pendidikan STIE Mitra Indonesia Yogyakarta, Volume 7 Nomor 1.

Helisia, M. (2019). Membangun Tradisi Entrepreneurship Pada Masyarakat. Jurnal Edunomika STIE AAS Surakarta. Vol. 03, No. 02.

Wahyu, Dwi. (2016). Membangun Perilaku Entrepreneur Pada Mahasiswa Melalui Entrepreneurship Education. Jurnal Bisnis Manajemen dan Akuntansi Vol. III, No 1. Rujukan Website:

https://economy.okezone.com/read/2019/04/09/320/2040896/syarat-jadi-negara-majujumlah-pengusaha-14-dari-rasio-penduduk (diakses pada 16 April 2020 pukul 18.00)

https://www.antaranews.com/berita/761556/rasio-kewirausahaan-indonesia-naikdalam-empat-tahun-terakhir (diakses pada 16 April 2020 pukul 19.00) 